\title{
Measuring Institutional Collaboration on Coping Flood and Rob in Panjang Baru Village Pekalongan City
}

\author{
Edi Purnomo ${ }^{1}$, Hadi Wahyono ${ }^{2}$ \\ \{edi.sj410@gmail.com ${ }^{1}$, hadi.wahyono@pwk.undip.ac.id ${ }^{2}$ \} \\ ${ }^{1,2}$ Department of Urban and Regional Planning, Diponegoro University, \\ Semarang, Indonesia
}

\begin{abstract}
Present Development planning in flood and rob (coastal floods) coping emphasizes collaboration, because the problems are too complex. It is very important to combine all of the stakeholder's resources for achieving common goals. Floods and rob have become a chronic problem for Pekalongan City, especially in Panjang Baru Village. Various treatments up to now have not been able to overcome the main problems and their emerged impacts. The coping by various stakeholders are still partial and oriented in an emergency situation. Institutional collaboration between all stakeholders is needed to maximize all resources. To reach the collaboration stage, it is necessary to measure the extent of the level and to find out how the collaboration map has been achieved by all stakeholders involved. Collaboration levels and maps can provide an overview of information about current collaboration achievements. The achievements understanding of existing collaborations can be used as an evaluation in reaching the collaboration stage. Quantitative method is used in this study, to measure the achievement level of collaboration using level of collaboration scale. This measurement also presented a map of collaboration among involved stakeholders. The measurement results obtained by the average value of collaboration are still low, not even reaching the level of coordination. The highest rating and anomalies from the values obtained are discussed in this study. Finally, the results of this study are expected to be an input and consideration for all stakeholders in overcoming flood and rob problems in Pekalongan City, especially in Panjang Baru Village.
\end{abstract}

Keywords: Institutional Collaboration, Measurement and Mapping, Flood and Rob, Pekalongan City.

\section{Introduction}

Global warming has affected the quality in several coastal cities' environmentin in the north coast of Java island making them vulnerable to flood and rob [1]. Flood and rob are influenced by the rising surface of the ocean and global warming [2]. Meanwhile, geology and meteorology phenomena such as soil and hurricane subsiden have become the main factor causing the $r o b$ [3]. Global warming has led to the melting iceberg at the north and south pole making the volume and surface of the ocean increase gradually. This situation is worsened by the declining level of the soil which allow sea water to flood the ground and leave puddles. On the other hand, $r o b$ is sea water invading bigger area on the ground caused by the tide [4]. The flood itself is temporary but the water left remains permanent, and $r o b$ is a unique term used to describe the phenomenon, especially for local people coming from the north coast of Java [5]. 
The water overflow originating from the ocean tide usually exceeds the normal limit allowing it to invade several residential areas. Even worse, the water stays for quite some time.

Eventually, water from flood and rob decrease the environment quality and communities quality of life. Floods and rob have a direct and indirect impact [6], [7]. The direct impact takes form in physical environment damage and health such as house, infrastructure, unsanitary environment and abnormal life. On the other side, the indirect impact is more to the social and economical loss [7], namely loss of livelihoods, economic instability and declining social quality. There is almost nothing that can be done to avoid flood from ocean tide other than adapting to the situation and environment or moving to a safer area [8]. Both option are equally difficult to choose and spend resources in terms of fund and technology.

It requires a strong sense inter-sector belonging and involvement from all stakeholders in order to soften the impact by avoiding waste of resources and bureaucracy complicacy which can increase the demand towards the institutions involved [9]. In order to do this, all elements must work together to have more efficient resources and bureaucracy. This method can be applied to highlight and overcome the impact of both flood and rob in most of Indonesia's coastal areas.

Some programs consider this type of collaboration can only achieve half of the expected final result [10]. Final result is not the only goal of the program because the juorney to reach to the final destination also has its own value. Forming a partnership or collaboration is certainly a part of the journey to reach the final result. Hence, this partnership can provide the extra hand to reach the goal more easily.

Multi-institutions partnership can reduce the organizations' operational cost and improve productivity at the same time [11]. This collaboration provides the cost saving solution since the operational cost can be handled together by all related organizations. By doing so, the problem can be solved by distributing the elements to all related organizations based on their interest and expertise. Thus, this can also improve each institution's performance.

Strengthening the vertical and horizontal understanding plays impecable role in building the awareness for adapting and managing the water resource effectively [12]. To coping flood and $r o b$ requires the participation of all stakeholders from all level government and citizen. This is inevitably significant in determining the long term plan and policy to manage water resource and to improve the ability in adapting to the flood.

Community need also to participate and actively involve in managing the environment [13]. This is related to the transfer of knowledge, appropriateness and community's capacity improvement. By involving all stakeholders, it is proven effectively in addressing numerous environmental issues.

Flood and rob are the main problems faced by the people living in Pekalongan. Water flooding almost the entire area in this city, especially Panjang Baru region. In the previous research Hapsoro \& Buchori claimed that, the scores have indicated that Panjang Baru Region is ranked as the region with the highest social and economic vulnerability due to the frequent flood disaster and the environment poor drainage system [14]. Without proper infrastructure, the water level covering the area will be hard to reduced. Hence, it creates unhealthy environment which eventually affects the social and economic life of the people.

Meanwhile, the local people's lack of knowledge relating to infrastructure and limited budget have become the main issues in implementing policies for addressing the flood and rob issues in the area [15]. Poor infrastructure and financial condition have resulted in a rather mediocre solution to the problem which is not as expected it would be.

Flood and rob can not be handled by only mitigating the disaster, but also by adapting to the people's social environment. Improving the house and the environment are just two of 
them [16]. Structurally, adaptation can only be done by adjusting the house to survive flood's and $r o b$ 's impact.

A good flood governance and adaptation are needed to reduce the impact. To achieve this, it is strongly influenced by policies, plans and programs issued by the government. In addition, the government also needs to socialize and empower the community to respond to flooding. The role of the government greatly influences achieving a good flood management and adaptation [17].

In this case, the municipal government of Pekalongan has taken several policies addressing the issue. These policies cover planning, budgeting, regulating, institutional collaborating and infrastructure development aspects [18]. It takes all stakeholders to cooperate in coping the rob flooding the city of Pekalongan [19]. Institutional collaboration is one of the aspects taken by the municipal government due to the complexity of the problem that cannot be solved by only one actor. In collaborative planning, party who requires support and assistance from other parties tend to be cooperative [20].

Previous collaboration in coping the flood and rob in Pekalongan is a semi-formal collaboration without any official agreement in reaching the goal with minimum result [19]. By far, all related institutions work together to deal with the flood and rob problems by using the substance and regulations from each related institution as the foundation. As a result, this collaboration still cannot manage to solve the problem in Pekalongan city effectively.

Many identified researches stressed the importance of stakeholder collaboration [21]. In order to reach the optimum effectivity, measuring the collaboration is significant. In terms of evaluating the program, the measurement often targets the improvement level of the collaboration as it can be identified vividly [22]. By recognizing the level of collaboration, the running program can be standardized.

To achieve the effectiveness, collaborators must be able to comprehend their strength and weakness of their collaboration [23]. Also, they must be able to measure their level of collaboration as it will guide them to achieve the most effective collaboration. The importance of measuring the level of collaboration can used as the evaluation material to decide the continuity of the collaboration. Hence, an effective inter-institution collaboration management can be achieved.

Due to the unoptimized collaboration in coping flood and rob in Pekalongan city, it is important to understand the level and the map of collaboration in progress. Therefore, the materials needed to evaluate the collaboration in Pekalongan city and Panjang Baru region to be specific can be obtained. For that purpose, this research is designed to measuring the level of institutional collaboration in coping flood and rob in Panjang Baru, Pekalongan. Hopefully, the result can provide the proper material to evaluate the effectiveness of the collaboration to speed the solution.

\section{Research Method}

This research used agent's approach in handling problems related to the disaster as the first assumed stakeholder involved in dealing with flood and rob in Pekalongan. As stated in the Head of BNPB regulation no. 4/2008 concerning on the guideline in planning the disaster coping activity, there are 2 (two) groups of agents, namely related government institution and the community [24].

The first group consists of several sectors such as government, health, social, public works, transportation, energy and mineral resources, workforce and transmigration, finance, 
forestry, environment, maritime, research institution and university, and the Indonesian National Armed Forces/police department. Meanwhile, the later group consists of the community, private institution, non-government institution, media and international institution.

In applying this approach, an initial list of involved agents was made as the future respondents. Then, several potential respondents were selected by using purposive sampling method. Next, another selection was conducted to filter those previously selected respondents and to complete the initial stakeholder list in Panjang Baru, Pekalongan city.

Data analisis was done using quantitative technique by adopting Level of Collaboration Scale (LCS) meassuring method used by Frey. LCS implements collaboration level model and likert scale by scoring each stakeholder's interaction with other stakeholders. Frey's collaboration level model was adopted for this research.

By using 5 (five) characteristics in level of people's interaction [25] plus 1 (one) lowest level with 0 (zero) as not connect at all, each respondent assess one's partner with a scale 0 (zero) to 5 (five) [22].

Each interaction may have different measurement from each stakeholder depends on each perception. It is possible that the assessor from one stakeholder may be scored differently by other stakeholders which may even get the lowest score or no interaction at all.

Eventually, result of the questionaire will come in a form of data consist of the level of interaction among stakeholders, and the collaboration level measurement among stakeholders. These data will then be presented in a table.

To maintain the measurement stability, reliability test was conducted. In this case, we used SPSS programs to make sure the answer are reliabel. To test the reliability, a response can be considered reliabel if it reaches cronbach' alpha $>0.6$.

After the total score is obtained from all assessing respondents, the score will divided by the total number of assessing respondents. In other words, a mean score will be obtained. This score will be the collaboration score for the respondents. All collaboration scores from each stakeholder will then be calculated to get the average score of the institution.

In mapping the stakeholders' collaboration process, the survey result from the previous stage was continued. The data obtained from LCS will be reported quantitatively in Collaborations Mapping (CM). By applying the collaboration map approach from Frey et al., line thickness scale and arrow's head direction, and circle will be used to define the collaboration level among entities visually in a collaboration map.

\subsection{Modification}

Based from Frey's collaboration map, one type of line added to the map to represent networking. The line was designated to distinguish it from no interaction at all which will be illustrated by no line. Long dash dot line was chosen to represent networking and long das line to represent cooperation. The top three level will be represented by solid lines with different thickness to illustrate the different level.

Modification was also done in the number of lines in Frey's collaboration map in which two lines were used previously to represent the score to and from a colleague. In reality, with so many stakeholders involved, this method will make the map looks messy. To overcome such problem, two scoring lines will be emerged with an arrow head to symbolize the scoring from and to other entities. 


\section{Results and discuscion}

The level of collaboration measurement was conducted by collecting the score for each stakeholder's perception presented in a table. The initial step was done by scoring the respondent's score reliability using SPSS. The score will then be presented by cronbach's alpha score. The result of relability test using SPSS shows the result of cronbach's alpha is 0.765 . Since cronbach's alpha $>0.6$, it can be concluded that the answer's mean is reliabel.

Next, the score from and to each stakeholder can be put in total in each entity's table. To obtain the collaboration score $(C)$, the total score from partner $(N 1)$ and the total score to partner $(N 2)$ are divided by the number of partners $(n-1)$.

Tables. The result of LCS can be summarized by displaying significant information like $N 1$ as the total score from each stakeholder's partner, $N 2$ as the total score to each stakeholder's partner, $C$ as the total collaboration score, $N o L$ as the amount of interaction for each stakeholder towards other stakeholders, see table 1

Table 1. level of collaboration scale scoring summary

\begin{tabular}{|c|c|c|c|c|c|}
\hline No & Stakeholder & $\mathrm{N} 1$ & $\mathrm{~N} 2$ & $\mathrm{C}$ & NoL \\
\hline 1 & $\begin{array}{l}\text { Pekalongan Municipal Regional Board for Disaster } \\
\text { Management (BPBD) }\end{array}$ & 67 & 33 & 2,08 & 13 \\
\hline 2 & $\begin{array}{l}\text { Pekalongan Municipal Regional Development Planning } \\
\text { Agency (BAPPEDA) }\end{array}$ & 57 & 63 & 2,50 & 15 \\
\hline 3 & Pekalongan Municipal Regional Health Office & 51 & 43 & 1,96 & 12 \\
\hline 4 & Pekalongan Municipal Regional Social Affairs Office & 64 & 78 & 2,96 & 17 \\
\hline 5 & $\begin{array}{l}\text { Pekalongan Municipal Regional Public Works and Spatial } \\
\text { Planning Office }\end{array}$ & 61 & 57 & 2,46 & 17 \\
\hline 6 & $\begin{array}{l}\text { Pekalongan Municipal Regional Settlement and } \\
\text { Residential Office }\end{array}$ & 53 & 63 & 2,42 & 18 \\
\hline 7 & Pekalongan Municipal Regional Transportation Office & 28 & 39 & 1,40 & 11 \\
\hline 8 & $\begin{array}{l}\text { Central Java Provincial Energy and Mineral Resources } \\
\text { Office }\end{array}$ & 19 & 15 & 0,71 & 3 \\
\hline 9 & $\begin{array}{l}\text { Pekalongan Municipal Regional Industry and } \\
\text { Employment Office }\end{array}$ & 22 & 24 & 0,96 & 3 \\
\hline 10 & Pekalongan Municipal Regional Board of Finance & 38 & 22 & 1,25 & 7 \\
\hline 11 & Pekalongan Municipal Regional Environment Office & 48 & 49 & 2,02 & 15 \\
\hline 12 & $\begin{array}{l}\text { Pekalongan Municipal Regional Marine and Fishery } \\
\text { Office }\end{array}$ & 28 & 42 & 1,46 & 10 \\
\hline 13 & $\begin{array}{l}\text { Diponegoro University Research Institute and Community } \\
\text { Service (LPPM) }\end{array}$ & 13 & 51 & 1,33 & 7 \\
\hline 14 & Indonesian National Armed Forces / Police Department & 63 & 10 & 1,52 & 2 \\
\hline 15 & Panjang Baru Local Government & 79 & 46 & 2,60 & 11 \\
\hline 16 & Karya Baru Community Self-Reliance Agency (BKM) & 50 & 57 & 2,23 & 11 \\
\hline 17 & $\begin{array}{l}\text { Panjang Baru Local Community Empowerment Agency } \\
\text { (LPM) }\end{array}$ & 50 & 42 & 1,92 & 8 \\
\hline 18 & Karya Pemuda Youth Organization & 49 & 48 & 2,02 & 9 \\
\hline 19 & Youth Disaster-Response Organization (Tagana) & 41 & 39 & 1,67 & 7 \\
\hline 20 & Disaster-Response Village (KSB) & 36 & 28 & 1,33 & 4 \\
\hline
\end{tabular}




\begin{tabular}{|c|c|c|c|c|c|}
\hline 21 & Hamlet (RW) & 53 & 32 & 1,77 & 10 \\
\hline 22 & $\begin{array}{l}\text { Central Java Provincial Board for Disaster Management } \\
\text { (BPBD) }\end{array}$ & 23 & 79 & 2,13 & 8 \\
\hline 23 & Non-Government Organization (Kemitraan) & 30 & 36 & 1,38 & 8 \\
\hline 24 & Media (Radar Pekalongan) & 35 & 36 & 1,48 & 13 \\
\hline 25 & Kotaku Program (Pekalongan City) & 39 & 65 & 2,17 & 13 \\
\hline
\end{tabular}

In the collaboration map, there is a scoring line from and to each staholder towards the others. One way scoring is shown by one way arrow. Different scoring is illustrated by different types of going and returning arrow. Other than the name of each stakeholder, the map is also completed with a box containing information about the amount of interaction and the collaboration average score. Also, the map is completed with the mean of interaction and the mean of collaboration obtained from all stakeholders.

Figures. The map illustrates the scoring of each stakeholder towards other stakeholders involved in solving the problems caused by flood and rob in Panjang Baru, Pekalongan see Figure 1. In the Collaboration Map, there is also several informations regarding the level of interaction and collaboration,

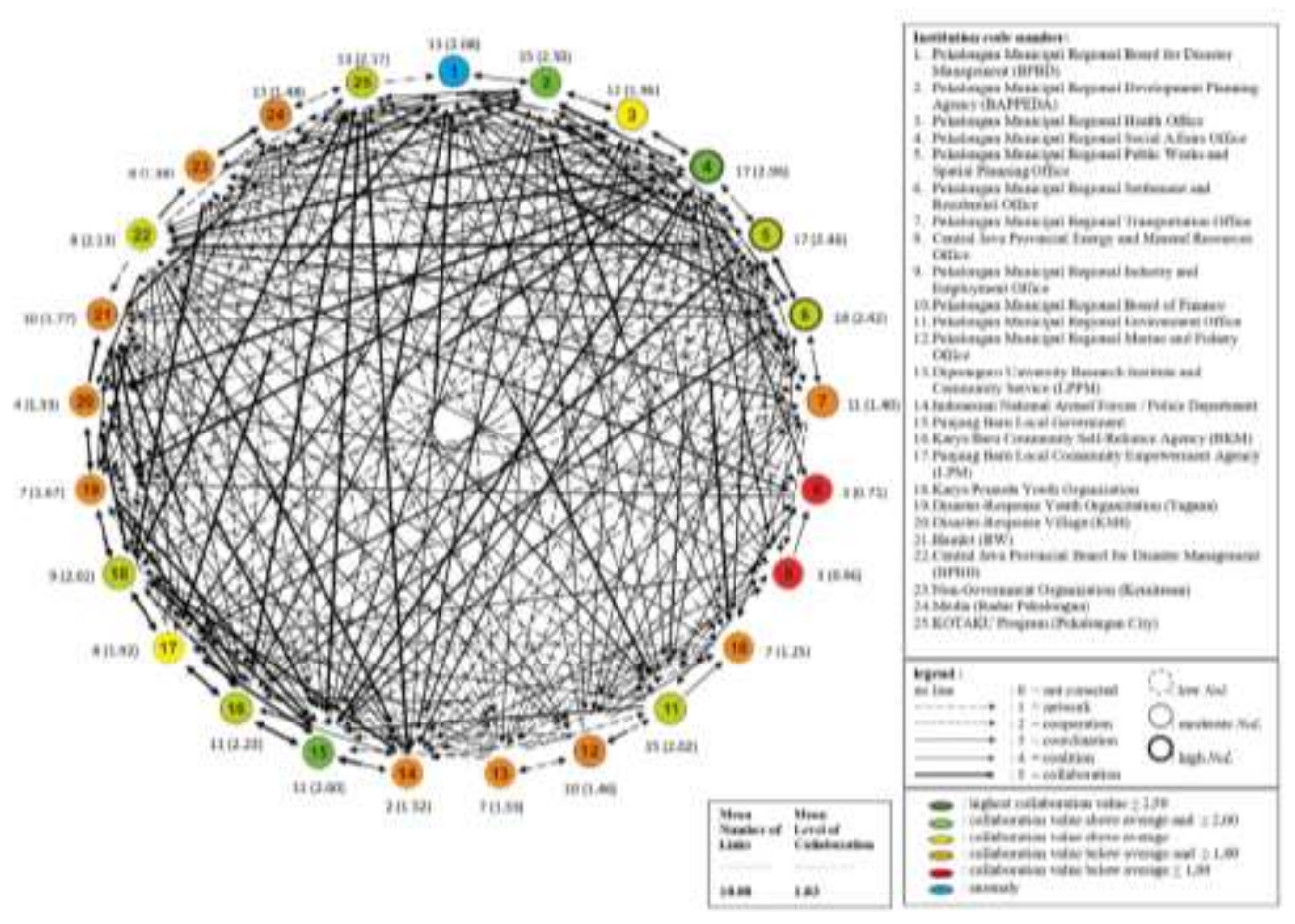

Figure 1. The institutional collaboration map in coping flood and rob in panjang baru village pekalongan city 
Based on the summary of LCS scoring table, the scoring ranks of the total score from partner, the total score towards partner, collaboration mean level and interaction perception level can be conducted.

The top three of total scoring from partner (N1) are Panjang Baru Local Government with 79 points, followed by Pekalongan Municipal Regional Board for Disaster Management (BPBD) with 67 points and Pekalongan Municipal Regional Social Affairs Office with 64 points. This information indicated that those stakeholders were considered well-interacting by their partners.

Panjang Baru local Government was considered significant by other stakeholders as it has direct authority in Panjang Baru area. Also, Pekalongan Municipal Regional Board for Disaster Management (BPBD) which obtained quite significant total score from other stakeholders because it is the only government institution in charge of coping with disaster. It has the main role in emergency situation led by the regional secretary to directly coordinate all stakeholders. Meanwhile, Pekalongan Municipal Regional Social Affairs Office stood on the third position since it is the only government institution supporting BPBD in distributing logistics aid to the victim. At the same time, it also organizes voluntary organization in form of Disaster-Response Youth Organization and empowers the society by assembling a DisasterResponse Village in certain areas which are quite vulnerable to disaster.

Based on the rank in total scoring towards partners (N2), the top three positions were taken by Central Java Provincial Board for Disaster Management (BPBD), Pekalongan Municipal Regional Social Affairs Office and Kotaku Program. This shows how high the stakeholders' concern in collaborating when coping with flood and rob in Panjang Baru, Pekalongan.

Central Java Provincial Board for Disaster Management (BPBD) is responsible for coordinating and collaborating all related sectors in coping with disaster in its provincial area. Also, Pekalongan Municipal Regional Social Affairs Office which collaborates in distributing the logistics aid. Meanwhile, Kotaku Program which deals with the city's slums management has crucial role in pre and post disaster phase. The development in Kotaku Program other than dealing with the slums can also prepare the infrastructure which can reduce the impact of flood and rob. In 2019, it manages the government 2 billion budget to build local roads and drainage system in Panjang Baru area.

The rank for the number of link (NoL) Pekalongan Municipal Regional Settlement and Residential Office, Pekalongan Municipal Regional Social Affairs Office and Pekalongan Municipal Regional Public Works and Spatial Planning Office as the top three.

Pekalongan Municipal Regional Settlement was considered significant due to its main role in managing the settlement and residential area affected by the disaster in the city.

On the other hand, the rank in the level of collaboration $(C)$ from each stakeholder indicates Pekalongan Municipal Regional Social Affairs Office, Panjang Baru local Government, and Pekalongan Municipal Regional Development Planning Agency as the top three with the scores of 2.96, 2.60, and 2.50, respectively. Meanwhile, the mean of all stakeholders' collaboration scores is 1.84. Pekalongan Municipal Regional Social Affairs Office is on the first position, because this institution is critically needed by others as logistics providers during the disaster response. Meanwhile Panjang Baru Local Government rank the second, because it requires help from other institutions.

It is interesting to see that the rank in the total score for partners (N2) presents Pekalongan City Municipal Regional Board for Disaster Management (BPBD) with a quite low score (33) ranked $19^{\text {th }}$. In fact, the institution considers the same as they only ranked the $4^{\text {th }}$ in the total score for number of link with 13 points. As a government institution which is responsible for 
coordinating all sectors in coping with disaster, the institution considers that the collaboration is not good enough. This was the result of poor assignments given to all stakeholders in the city scale. Every government institution only holds its own job description. According to key information, standard operational procedures are required in dealing with flood and rob. The city needs to arrange and decide a contingency plan in coping with the disaster in the city. Also, it is intriguing to know that $r o b$ is actually not considered as a disaster based on the government policy. Therefore, it stops the regional board for disaster management (BPBD) in developing and engaging themselves in dealing with rob.

\section{Conclusion}

It can be concluded that the result shows that collaboration does exist, but it has not reached its maximum potential as overall it only reaches 1.84 in average. This means that it only reaches the level of cooperation. Hence, it requires a strategy to increase the quality of the collaboration.

It is recommended that the Pekalongan Municipal Government needs to arrange and legalize the contingency plan in dealing with flood and rob, increase the budget for coping with disaster, and involve all stakeholders especially the citizens affected by the disaster in all phase of the disaster management. Meanwhile, the central government needs to consider classifying rob as a disaster.

\section{Acknowledgements}

The authors would like to express their gratitude to the Republic Indonesia's Ministry of Public Works and Public Housing which supported the funding of the research.

\section{References}

[1] I. Buchori et al., "A predictive model to assess spatial planning in addressing hydrometeorological hazards: A case study of Semarang City, Indonesia," Int. J. Disaster Risk Reduct., vol. 27, no. April 2017, pp. 415-426, Mar. 2018.

[2] A. W. Sejati and I. Buchori, "A GIS Model for Predicting Disaster Prone Areas Affected by Global Sea-Level Rise: a Case Study of Semarang City," ICRD Int. Conf., pp. 5-12, 2010

[3] E. Chaussard, F. Amelung, H. Abidin, and S. H. Hong, "Sinking cities in Indonesia: ALOS PALSAR detects rapid subsidence due to groundwater and gas extraction," Remote Sens. Environ., vol. 128, pp. 150-161, 2013.

[4] I. Rudiarto, D. Pamungkas, H. Annisa A., and K. Adam, "Kerentanan Sosio-Ekonomi terhadap Paparan Bencana Banjir dan Rob di Pedesaan Pesisir Kabupaten Demak," J. Wil. dan Lingkung., vol. 4, no. 3, p. 153, Dec. 2016.

[5] I. Buchori, A. Pramitasari, A. Sugiri, M. Maryono, Y. Basuki, and A. W. Sejati, "Adaptation to coastal flooding and inundation: Mitigations and migration pattern in Semarang City, Indonesia," Ocean Coast. Manag., vol. 163, no. November 2017, pp. 445-455, Sep. 2018. 
[6] I. Gumilar, H. Z. Abidin, T. P. Sidiq, H. Andreas, R. Maiyudi, and M. Gamal, "Mapping And Evaluating The Impact Of Land Subsidence In Semarang ( Indonesia )," Indones. J. Geospasial, vol. 2, no. 2, pp. 26-41, 2013.

[7] A. L. Nugraha, P. B. Santosa, and T. Aditya, "Dissemination of Tidal Flood Risk Map Using Online Map in Semarang," Procedia Environ. Sci., vol. 23, no. Ictcred 2014, pp. 64-71, 2015.

[8] L. Parker, "Sea level rise will flood hundreds of cities in the near future," National Geographic, 31-Aug-2017. [Online]. Available: https://news.nationalgeographic.com/2017/07/ sea-level-rise-flood-global-warmingscience/.

[9] K. Oldham and K. Astbury, "Evolution of disaster risk governance in Greater Manchester: a case study from the UK," Procedia Eng., vol. 212, no. 2017, pp. 7-14, 2018.

[10] H. P. Greenwald and A. P. Zukoski, "Assessing Collaboration: Alternative Measures and Issues for Evaluation," Am. J. Eval., vol. 39, no. 3, pp. 322-335, 2018.

[11] M. J. Donohue, "How multiagency partnerships can successfully address large-scale pollution problems: a Hawaii case study," Mar. Pollut. Bull., vol. 46, no. 6, pp. 700702, Jun. 2003.

[12] A. Azhoni, I. Holman, and S. Jude, "Adapting water management to climate change: Institutional involvement, inter-institutional networks and barriers in India," Glob. Environ. Chang., vol. 44, no. April 2016, pp. 144-157, May 2017.

[13] N. Yuliastuti, H. Wahyono, S. Syafrudin, and S. Sariffuddin, "Dimensions of Community and Local Institutions' Support: Towards an Eco-Village Kelurahan in Indonesia," Sustainability, vol. 9, no. 2, p. 245, Feb. 2017.

[14] A. W. Hapsoro and I. Buchori, "Kerentanan Sosial dan Ekonomi Terhadap Bencana Banjir Studi Kasus, Kajian Pesisir Kota Pekalongan,” Tek. Perenc. Wil. Kota, vol. 4, no. 4, pp. 542-553, 2015.

[15] R. F. Ramadhanni, B. Setiyono, and D. G. Manar, "Implementasi Program Penanganan Banjir Rob di Wilayah Pesisir Kota Pekalongan,” J. Polit. Gov. Stud., vol. 5, no. 4, pp. 261-270, 2015.

[16] P. Khadiyanta and S. Dewantari, "Settlement Adaptation by Reshaping Dwellings in the Degrading Area at Genuk Disctrict of Semarang City, Indonesia," Procedia - Soc. Behav. Sci., vol. 227, no. November 2015, pp. 309-316, Jul. 2016.

[17] A. Ghozali, Ariyaningsih, R. B. Sukmara, and B. U. Aulia, "A Comparative Study of Climate Change Mitigation and Adaptation on Flood Management between Ayutthaya City (Thailand) and Samarinda City (Indonesia)," Procedia - Soc. Behav. Sci., vol. 227, no. November 2015, pp. 424-429, 2016.

[18] Y. Hardianto, “Analisis Kebijakan Penanggulangan Banjir Pasang Air Laut (Rob) Di Kota Pekalongan," Gadjah Mada University, 2017.

[19] T. Mutiarawati and S. Sudarmo, "Collaborative Governance dalam Penanganan Rob di Kelurahan Bandengan Kota Pekalongan,” J. Wacana Publik, vol. 1, no. 2, pp. 48-62, 2017.

[20] H. Wahyono, A. Djunaedi, B. Setiawan, and L. Subanu, "Collaborative Planning on Cross-Border Water Supply Service In Surakarta City Border Area , Indonesia *)," Indones. J. Plan. Dev., vol. 1, no. 1, pp. 11-18, 2014.

[21] R. E. Freeman and J. McVea, "A Stakeholder Approach to Strategic Management," Virginia, 1-2, 2001.

[22] B. B. Frey, J. H. Lohmeier, S. W. Lee, and N. Tollefson, "Measuring collaboration 
among grant partners," Am. J. Eval., vol. 27, no. 3, pp. 383-392, 2006.

[23] L. I. Marek, D. J. P. Brock, and J. Savla, "Evaluating Collaboration for Effectiveness: Conceptualization and Measurement," Am. J. Eval., vol. 36, no. 1, pp. 67-85, 2015.

[24] BNPB, Peraturan Kepala Badan Nasional Penanggulangan Bencana Nomor 4 Tahun 2008 Tentang Pedoman Penyusunan Rencana Penanggulangan Bencana. 2008, p. b.

[25] T. Hogue, "Community Based Collaboration: Community wellness multiplied," Oregon Center for Community Leadership, Oregon State University, 1993. [Online]. Available: http://www.uvm.edu/crs/nnco/collab/wellness.html. [Accessed: 27-Sep2018]. 